\title{
IAMJ
}

INTERNATIONAL

AYURVEDIC

MEDICAL JOURNAL

\section{MANAGEMENT OF HYPERURICEMIA(GOUT) THROUGH AYURVEDA: A CASE STUDY}

\section{$\underline{\text { Nabaruna Bose }}{ }^{1}$, Shyamanta Kalita $^{2}$}

${ }^{1}$ PG Scholar, Dept. of Kayachikitsa, Govt. Ayurvedic College, Guwahati-14, Assam, India

${ }^{2}$ Lecturer, Dept. of Kayachikitsa, Govt. Ayurvedic College, Guwahati-14, Assam, India

Corresponding Author: bose.nabaruna@gmail.com

https://doi.org/10.46607/iamj4109072021

(Published Online: July 2021)

Open Access

(C) International Ayurvedic Medical Journal, India 2021

Article Received: 14/06//2021 - Peer Reviewed: 24/06/2021 - Accepted for Publication: 25/06/2021

\section{Check for updates}

\begin{abstract}
The rapid modernization in India, fast-food culture, stressful and speedy life is causing several lifestyle disorders. Gout is a metabolic disease that most often affects middle-aged to elderly men and post-menopausal women. It results from an increased body pool of urate with hyperuricemia. It is typically characterized by episodic acute arthritis or chronic arthritis caused by deposition of monosodium urate crystals in joints and connective tissue tophi and the risk for deposition in kidney interstitium or uric acid nephrolithiasis. Vatarakta (gouty arthritis) is a chronic disease in which derangement of metabolism, occurs due to indulgence in unwholesome dietary habits and lifestyle. Vatarakta is caused by vitiated Vata and Rakta simultaneously. Initially vitiated Vata obstructs the path of vitiated Rakta and then gets obstructed by Rakta itself. It can be correlated with Gouty Arthritis due to their similarity in the clinical presentation. It is characterised by severe pain, tenderness, inflammation and burning sensation in the affected joints. A 34-year-old male patient came to Kayachikitsa OPD of Government Ayurvedic College and Hospital, Guwahati presenting with complaints of pain and swelling in the right first metatarsophalangeal joint, burning sensation of both the sole, right ankle joint pain and swelling along with pain in the right elbow from last 4 months. The patient was subjected to both panchakarma therapy and oral medication and at the end of the treatment Serum Uric acid level came down from $8.6 \mathrm{mg} / \mathrm{dl}$ to $5.4 \mathrm{mg} / \mathrm{dl}$.
\end{abstract}


Keywords: Gout, Vatarakta, Ksheera basti, Amritadi guggulu, Kokilaksha Kasaya.

\section{INTRODUCTION}

The health of an individual depends solely on his/her diet and lifestyle. Due to faulty dietary habits and lifestyles, human beings are more vulnerable to metabolic disorders. These disorders may be causing functional impairment or crippling disorders like Vatarakta. Incidence of gouty arthritis is $0.2-2.5$ per 1000. Overall prevalence is $2-26$ per 1000 . Gout is rare in children and premenopausal women in India. Out of the affected population, males are more common while the female of postmenopausal age is at more risk ${ }^{[1]}$. Vatarakta is caused by vitiation of Vata and Rakta simultaneously ${ }^{[2]}$. Both Vata prakopak and Rakta prakopak nidan are involved in Samprapti of the disease ${ }^{[2]}$. When a person does not opt for purification processes like Vamana and Virechana or due to trauma, Rakta dhatu gets vitiated. The same individual with vitiated Rakta dhatu when starts taking Vata-prakopakahara and Vihara, there occurs Vata-vridhhi. In this condition, the already vitiated Raktadhatu obstructs the path of Vridhha vata, in which the Vata has to flow. Vitiated Vata becomes Aavrita with vitiated Raktadhatu. Vridhha and obstructed Vata inturn vitiates the whole Rakta and manifests as Vatarakta ${ }^{[3]}$. It is of two types Uthana and Gambhira Vatarakta ${ }^{[4]}$. Gambhira Vatarakta mainly affects Asthidhatu and the joints and causes Daha, Toda, Sphurana, Sotha etc. Gout is characterised by severe pain, tenderness, inflammation and burning sensation in the affected joints can be co-related with Gambhira Vatarakta.

\section{Case Study}

\section{Chief Complaints}

A 34-year-old male patient came to Kayachikitsa, OPD of Govt. Ayurvedic College and Hospital, Guwahati with complaints of pain and swelling in right first metatarsophalangeal joint (big toe), right ankle joint, burning sensation of both the sole along pain in the right elbow from last 4 months. The pain became severe in the last 15 days for which he was unable to do his daily activities. He took Febuxostat $40 \mathrm{mg}$ for 3 months but only got temporary relief. The pain increases with the application of warm substances over it. He also complains of stiffness over the elbow joint and finds difficulty in walking too.

On doing investigation Serum Uric acid level came as $8.6 \mathrm{mg} / \mathrm{dl}$ on $24 / 03 / 21$. He was then asked to get admitted for further treatment.

Aim and Objective: To study the effect of Ayurvedic treatment in the management of Vatarakta.

\section{Materials And Methods}

Centre of Study: Govt. Ayurvedic College and Hospital, Guwahati.

Single Case Study.

\section{Treatment Plan:}

Treatment was planned to keep the symptoms in mind.

Table 1: Showing materials used in the study.

\begin{tabular}{|l|l|l|l|l|}
\hline S1 No & Dravya & Dose & Anupana & Duration \\
\hline 1 & $\begin{array}{l}\text { Eranda Taila }+ \text { Triphala Kwatha }+ \text { Guduchi } \\
\text { Satwa }\end{array}$ & $\begin{array}{l}30 \mathrm{ml}+ \\
30 \mathrm{ml}+3 \mathrm{~g}\end{array}$ & Lukewarm water at bedtime & 3 nights \\
\hline 2 & Tab Amritadi Gugglu & $250 \mathrm{mg}$ & Lukewarm water after food thrice daily & 8 days \\
\hline 3 & Kokilaksha kasaya & $30 \mathrm{ml}$ & Lukewarm water after food twice daily & 8 days \\
\hline 4 & Sarivadyasava & $30 \mathrm{ml}$ & Lukewarm water after food twice daily & 8 days \\
\hline 5 & Ksheera Basti & $300 \mathrm{ml}$ & Daily & 8 days \\
\hline
\end{tabular}


For clearing the Kostha, Virechan with Sneha Dravya i.e., Eranda taila (30ml), Triphala Kwatha $(30 \mathrm{ml})$, Guduchi Satwa (1tsf) was given for 3 days.

After that Amritadi Gugglu, Kokilaksha kasaya, Sarivadyasava was started along with Ksheera Basti (Ksheera+Ghrita+Guduchi) for 8 days.
The patient was asked to avoid alcohol, meat, Tomato, Beans, Urada dal, Lentils, Curd and hot and spicy food.

Table 2: Treatment Given after 8 days

\begin{tabular}{|l|l|}
\hline At every Follow-up & Treatment given \\
\hline $1^{\text {st }}$ follow up after 7 days & - Kaishore Guggulu $250 \mathrm{mg}$ twice daily after food with lukewarm water. \\
& - Kokilaksha Kasaya $40 \mathrm{ml}$ twice daily after food with lukewarm water. \\
& - Sarivadyasava $30 \mathrm{ml}$ twice daily after food with lukewarm water. \\
\hline $2^{\text {nd }}$ follow up after 7 days & - Tab Gokshura $250 \mathrm{mg}$ twice daily after food with lukewarm water. \\
& - Kaishore Guggulu $250 \mathrm{mg}$ twice daily after food with lukewarm water. \\
& - Tab Guduchi $250 \mathrm{mg}$ twice daily after food with lukewarm water. \\
& - Kokilaksha Kasaya 40ml twice daily after food with lukewarm water. \\
\hline $3^{\text {rd }}$ follow up after 7 days & - Sarivadyasava $30 \mathrm{ml}$ twice daily after food with lukewarm water. \\
& - Ekrutadi guggulu $250 \mathrm{mg}$ thrice daily after food with lukewarm water. \\
& - Kokilaksha Kasaya $40 \mathrm{ml}$ twice daily after food with lukewarm water. \\
& - Tab Guduchi $250 \mathrm{mg}$ twice daily after food. \\
\hline
\end{tabular}

Table 3: Showing changes in symptoms before and after treatment.

\begin{tabular}{|l|l|l|l|}
\hline Sl No & Symptoms & Before treatment & After treatment \\
\hline 1 & Pain in the right big toe, ankle joint & Severe & Mild \\
\hline 2 & Swelling in the ankle joint & Present & Absent \\
\hline 3 & Burning sensation of both the soles & Present & Absent \\
\hline 4 & Stiffness over the elbow joint & Present & Absent \\
\hline
\end{tabular}

Table 4: Showing changes in Sr. Uric acid levels.

\begin{tabular}{|l|l|}
\hline Before Treatment $(24 / 03 / 21)$ & $8.6 \mathrm{mg} / \mathrm{dl}$ \\
\hline After Treatment $(21 / 04 / 21)$ & $5.4 \mathrm{mg} / \mathrm{dl}$
\end{tabular}

\section{RESULT}

The patient had started improving during the hospital stay and at the end of the 8th day there was a regression in the symptoms and after the completion of treatment Serum uric acid levels came down to normal.

\section{DISCUSSION}

Vatarakta is a more distressing and common metabolic disorder prevalent in the present era. Vatarakta is caused by vitiation of Vata and Rakta simultaneously. Both Vata prakopak and Rakta prakopak nidan are involved in Samprapti of the disease. It is characterised by severe pain, tenderness, inflammation and burning sensation in the affected joints. The aetiological factors responsible for Gouty arthritis, pathology and clinical features are quite similar to the Vatarakta. Gout is also known as the "disease of kings" and also "king of diseases" in modern medicine.

The action of Drugs and other procedure used are: 
$\checkmark$ Kaishor guggulu mentioned in Sharangdhar Samhita madhyam khanda 7/70-81 is Tridoshaghna, Rasayana, Vataraktahara

$\checkmark$ Kokilaksha kashay mentioned in Bhaishajya Ratvali, Vatarakta Rogadhikara 27/13 is used in Vatarakta and is Madhura and Shita in nature, it is also Shothaghna, shoolaghna.

$\checkmark$ Amrutadi guggulu mentioned in Bhavaprakash madhyam khanda, Vatarakta chikitsa. It is mainly Vata pitta shamaka.

$\checkmark$ Sarivadyasava mentioned in Bhaishajya Ratnavali, Pramehapidikachikitsa 38/22-27 is Pitta shamaka and is used in Vatarakta.

$\checkmark$ Ekangaveer rasa mentioned in Brihat Nighantu Ratnakara, Vatvyadhi chikitsa is Vata kapha shaman Brimhana, Rasayana.

$\checkmark \quad$ Mode of action of Snehana: Snehana helps in the proper Gati of Vata, brings Gaatra Mardavata and removes the Srothorodha. Sneha overcomes Rukshata by its Snigdha property and the Sanga is corrected.

$\checkmark$ Mode of action of Virechana: Ushna guna does Srothoshuddi and Ama pachana, so it relieves stiffness. Snigdha Virechana is given to expel out the vitiated Dosha. Due to the elimination of Kleda, laghuta is achieved. Stambha, Gaurav, Swayathu are the symptoms of Vatarakta.

$\checkmark$ Mode of action of Basti: Basti is the best therapy to control the Vata and thus it controls the Pitta and Kapha also. The given Basti is a mridu Niruha vasti when enters the Pakvasaya by its Virya, draws the vitiated Doshas lodged in the entered body from foot to the head, just as the sun situated in the sky sucks up the moisture from the earth. Ghrita misrita Kshira vasti is the best treatment for Vatarakta by Acharya Charaka and in Astanga Hridaya.

\section{CONCLUSION}

Since treatment for Vatarakta is limited in Modern science, Ayurvedic management of chronic Vatarakta can be an effective therapy. On understanding proper Nidan, Lakshana and Samprapti of Vatarakta we can treat it successfully with Oral medications along with panchakarma therapy. The medicines are given to the patient mainly fall under the categories of Tikta kashay rasa, Laghu rooksha guna, Ushna veerya and either Kaphavata hara or Pittavata hara mainly used for Deepan paachan and Rakta prasadana. The patient showed relief in symptoms and the laboratory findings of Serum Uric acid had lowered significantly. Therefore, the given Ayurvedic treatment along with pathya and apathy was successful in curing the disease without landing into a further complication.

\section{REFERENCES}

1. Sainani GS. API Textbook of Medicine. 6th ed. Mumbai: Association of Physicians of India; 1999

2. Shastri Kashinath, Chaturvedi Gorakhnath edited Charak Samhita of Agnivesha, Revised by Charak and Dridhabala, Part I, Chaukhamba Bharati Academy, Varanasi, Reprint, 2009; Chikitsa Sthana 29/5-6: Page no.820.

3. Shastri Kashinath, Chaturvedi Gorakhnath edited Charak Samhita of Agnivesha, Revised by Charak and Dridhabala, Part I, Chaukhamba Bharati Academy, Varanasi, Reprint, 2009; Chikitsa Sthana 29/9-10: Page no.820.

4. Shastri Kashinath, Chaturvedi Gorakhnath edited Charak Samhita of Agnivesha, Revised by Charak and Dridhabala, Part I, Chaukhamba Bharati Academy, Varanasi, Reprint, 2009; Chikitsa Sthana 29/19: Page no.822.

\section{Source of Support: Nil \\ Conflict of Interest: None Declared}

How to cite this URL: Nabaruna Bose: Management Of Hyperuricemia (Gout) Through Ayurveda: A Case Study. International Ayurvedic Medical Journal \{online\} 2021 \{cited July 2021\} Available from: http://www.iamj.in/posts/images/upload/1571_1574.pdf 